\title{
Autolysis in vitro of the Stipe Cell Wall in Coprinus macrorhizus
}

\author{
By TAKASHI KAMADA, * YUZO HAMADA AND \\ TSUNEO TAKEMARU \\ Department of Biology, Faculty of Science, Okayama University, Okayama 700, Japan
}

(Received 9 July 1981)

\begin{abstract}
Cell walls isolated from rapidly elongating stipes of Coprinus macrorhizus basidiocarps lost $55 \%$ of their dry weight during $24 \mathrm{~h}$ incubation at $37^{\circ} \mathrm{C}$. Neutral sugars accounted for $73 \%$ of the solubilized products, glucose being the major sugar component. In the carbohydrate fraction solubilized after relatively short periods of autolysis, polymeric (degree of polymerization $>10$ ), dimeric and monomeric components were detected, and the larger components were converted to monosaccharide as the reaction proceeded. Three polysaccharide fractions of the cell wall were highly susceptible to autolytic enzymes, whereas another fraction was not. Chitin appeared to be relatively resistant. Analyses of the cell walls from various stages during stipe elongation revealed a positive relation between the rate of stipe elongation and the initial rate of autolysis, suggesting that the autolytic enzymes are involved in the mechanisms of stipe elongation.
\end{abstract}

\section{INTRODUCTION}

Stipe elongation during basidiocarp maturation in Coprinus macrorhizus is caused by the elongation of component cells, and the rate of elongation is conspicuously high (Kamada \& Takemaru, 1977a). Thus, stipe elongation offers a useful system for clarifying the mechanism of hyphal cell elongation. The synthesis of chitin, a major component of the stipe cell wall, is required for stipe elongation (Gooday, 1973, 1975; Gooday et al., 1976). On the other hand, it has been found that the mechanical properties of the stipe cell wall change in parallel with the elongation rate (Kamada \& Takemaru, 1977a), and that some polysaccharide components of the cell wall decrease per unit stipe length as the stipe elongates (Kamada \& Takemaru, 1977b). These results suggest that the degradation of cell-wall components is also involved in the elongation process. Recently, Kamada et al. (1980) detected $(1 \rightarrow 3)$ $\beta$-glucanase, $(1 \rightarrow 6)$ - $\beta$-glucanase and chitinase activities in the crude cell-wall fraction of the stipe. However, there is no information about the activity of these wall-bound enzymes in situ, and their role in the elongation process is poorly understood. In the present study, the stipe cell walls of $C$. macrorhizus were autolysed in vitro, and the autolysing cell walls and their soluble products were analysed, in an attempt to obtain information concerning these problems.

\section{METHODS}

Organism and culture conditions. The wild-type dikaryotic stock (\#5026+5132) of Coprinus macrorhizus Rea. f. microsporus Hongo was used. Moore et al. (1979) have pointed out that this fungus is a member of the taxon Coprinus cinereus. For fruiting, an agar block with mycelium $(2 \mathrm{~mm} \times 2 \mathrm{~mm})$ was inoculated on the centre of CY-1 medium in Petri dishes $9 \mathrm{~cm}$ in diameter and incubated at $28^{\circ} \mathrm{C}$ under a regime of $12 \mathrm{~h}$ light $/ 12 \mathrm{~h}$ dark (Kamada \& Takemaru, 1977a). The medium contains, per litre, $20 \mathrm{~g}$ glucose, $2 \mathrm{~g}$ peptone, $1 \mathrm{~g}$ yeast extract, $0.46 \mathrm{~g} \mathrm{KH}_{2} \mathrm{PO}_{4}, 1 \mathrm{~g} \mathrm{~K}_{2} \mathrm{HPO}_{4}, 0.5 \mathrm{~g} \mathrm{MgSO}_{4} .7 \mathrm{H}_{2} \mathrm{O}$ and $15 \mathrm{~g}$ agar. The light was supplied from white fluorescent lamps providing approximately $500 \mathrm{~lx}$ at dish level. When basidiocarp primordia had appeared on the mycelial mat, the lid of the Petri dish was replaced with an inverted beaker $15 \mathrm{~cm}$ in depth and $9 \mathrm{~cm}$ in diameter, which was 
supported on the rim of the dish and held by pieces of adhesive tape. Under these culture conditions, basidiocarp maturation occurred 10 or $11 \mathrm{~d}$ after inoculation.

Preparation of stipe cell walls. Stipes (approx. $1 \mathrm{~g}$ fresh weight) were immersed in $20 \mathrm{ml}$ Mcllvaine buffer (pH 5.0) (Mcllvaine, 1921) containing $0.01 \%(\mathrm{w} / \mathrm{v})$ sodium azide to prevent bacterial contamination, homogenized in a Waring blender for $1 \mathrm{~min}$ at maximum speed, and then broken with a French press (Ohtake model 5615, Tokyo, Japan) operated at $23000 \mathrm{lbf} \mathrm{in}^{-2}(159 \mathrm{MPa})$. The cell-wall fraction was purified by low-speed centrifugations according to the method of Santos et al. (1979) with modification: it was washed twice with McIlvaine buffer ( $\mathrm{pH} \mathrm{5.0)}$ containing $0.01 \%(\mathrm{w} / \mathrm{v})$ sodium azide and $0.75 \mathrm{M}-\mathrm{NaCl}$ and then three times with the same buffer containing sodium azide only. All the above operations were carried out at $4{ }^{\circ} \mathrm{C}$.

To obtain cell walls free of autolytic activity, the cell-wall suspension obtained as above was boiled for $10 \mathrm{~min}$.

Dry weight determination of isolated cell walls. The cell-wall suspension was boiled for 10 min to terminate autolysis. The cell walls were washed three times with distilled water and then with increasing concentrations of ethyl alcohol, to absolute alcohol, by low-speed centrifugations. Finally, the pellet was dried to constant weight at $37^{\circ} \mathrm{C}$.

Autolysis of isolated cell walls. Cell walls obtained from approximately $1 \mathrm{~g}$ fresh weight of stipes were suspended in $10 \mathrm{ml} \mathrm{Mcllvaine} \mathrm{buffer} \mathrm{(} \mathrm{pH} \mathrm{5.0)}$ containing $0.01 \%(\mathrm{w} / \mathrm{v})$ sodium azide, and incubated with continuous shaking $\left(50\right.$ strokes $\mathrm{min}^{-1}$ ) at $37^{\circ} \mathrm{C}$. The dry weight of cell walls per $\mathrm{g}$ fresh weight of stipes ranged from $11 \cdot 3 \mathrm{mg}$ to $24.1 \mathrm{mg}$ according to the stage of stipe elongation. To analyse products liberated by autolysis, the suspension was centrifuged at low speed and $1 \mathrm{ml}$ of the supernatant was withdrawn.

Fractionation of cell-wall polysaccharides. Cell-wall polysaccharides other than chitin were fractionated into four fractions according to a minor modification of the method of Wessels (1965) as previously described (Kamada \& Takemaru, 1977b): fraction I is a polysaccharide extracted with $0.5 \mathrm{M}$-acetic acid at $75^{\circ} \mathrm{C}$, and fractions II, III and IV correspond, respectively, to S-glucan, an alkali- and acid-soluble polysaccharide, and R-glucan of Schizophyllum commune, on the basis of solubility characteristics.

Gel chromatography. A $1 \mathrm{ml}$ portion of soluble autolytic products was boiled for $10 \mathrm{~min}$ to terminate autolysis and applied to a Bio-Gel P-2 column (Bio-Rad, 200-400 mesh; $1.1 \times 80.0 \mathrm{~cm}$ ) previously equilibrated with Mcllvaine buffer ( $\mathrm{pH} 5.0$ ) containing $0.01 \%\left(\mathrm{w} / \mathrm{v}\right.$ ) sodium azide. The elution rate was $4.3 \mathrm{ml} \mathrm{h}^{-1}$. Fractions of $1 \mathrm{ml}$ were collected and analysed for sugar content.

Gas chromatography. The soluble autolytic products were boiled for $10 \mathrm{~min}$ to terminate autolysis and dried in vacuo at $35^{\circ} \mathrm{C}$. The samples were hydrolysed in $3 \mathrm{M}-\mathrm{HCl}$ at $100^{\circ} \mathrm{C}$ for $3 \mathrm{~h}$ and then neutralized with $\mathrm{NaOH}$ according to the method of Griggs et al. (1971). The resulting monosaccharides were converted to the alditol acetate derivatives and analysed using a gas-liquid chromatograph (Hitach model 163, Tokyo, Japan), according to the procedure of Griggs et al. (1971).

Chemical assays. Total carbohydrate content was determined with the anthrone reagent (Fairbairn, 1953) using glucose as standard. Protein was measured by the Lowry method, using bovine serum albumin as standard.

\section{RES ULTS}

\section{Autolysis of isolated cell walls}

Under the culture conditions described in Methods, stipe elongation during basidiocarp maturation proceeds in a synchronous manner (Kamada \& Takemaru, 1977a). The rate of stipe elongation increased up to $18 \mathrm{~h}$ after the start of illumination on the day of maturation and then decreased rapidly. Elongation ended by $24 \mathrm{~h}$. Cell walls isolated from stipes at $15 \mathrm{~h}$ showed a high autolytic capacity. In a $24 \mathrm{~h}$ incubation period, they lost $55 \%$ of their dry weight, and $400 \mu \mathrm{g}$ neutral sugar and $80 \mu \mathrm{g}$ protein equivalents per $\mathrm{mg}$ of their dry weight were detected in the supernatant of the reaction mixture. Gas chromatography revealed that the major component of the carbohydrate liberated by autolysis was glucose $(86.2 \%)$, with small amounts of $N$-acetylglucosamine $(7.0 \%)$, galactose $(3.1 \%)$, rhamnose $(1.6 \%)$, arabinose $(1.2 \%)$ and mannose $(0.9 \%)$. This indicates that neutral sugar is a major product of autolysis. Boiled cell walls released only a negligible amount of neutral sugar (Fig. 1), showing that the release of the sugar is enzymic. In the $\mathrm{pH}$ range 2.2 to 8.0 , sugar release was most rapid at $\mathrm{pH} 5 \cdot 0$.

The time-course study revealed that the rate of autolysis declined as autolysis proceeded (Fig. 1). In an attempt to understand the cause for the decline, autolysis was followed after the addition of boiled cell walls to the reaction mixture which had been incubated for $12 \mathrm{~h}$. The boiled cell walls clearly increased the autolysis rate (Fig. 1), suggesting that substrate 


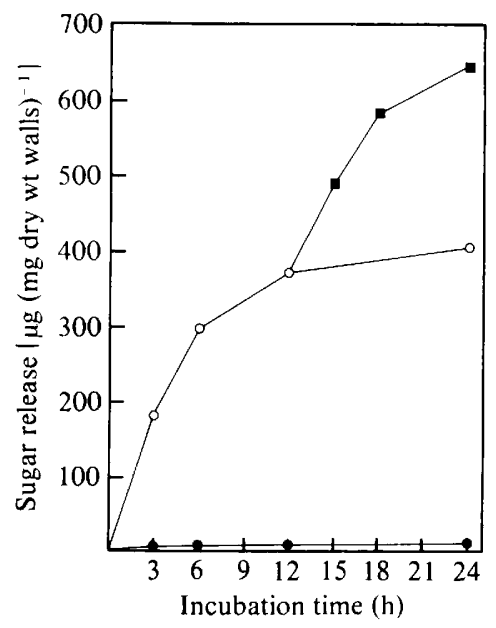

Fig. 1. Autolysis of isolated cell walls of the Coprinus macrorhizus stipe. Freshly prepared (O) and boiled $(O)$ cell wall samples ( $13 \mathrm{mg}$ dry wt) from stipes $15 \mathrm{~h}$ after the start of illumination on the day of basidiocarp maturation were incubated at $37^{\circ} \mathrm{C}$ in Mcllvaine buffer ( $\mathrm{pH} \mathrm{5.0)}$ containing $0.01 \%(\mathrm{w} / \mathrm{v})$ sodium azide, and the liberation of neutral sugar was followed as described in Methods. In another experiment, after $12 \mathrm{~h}$ incubation of freshly prepared cell walls (13 $\mathrm{mg}$ dry wt), boiled cell walls $(13 \mathrm{mg}$ dry wt) were added to the reaction mixture, and the release of the sugar was followed ( $\mathbf{D})$. Sugar release is expressed as $\mu \mathrm{g}$ anthrone-positive materials released per $\mathrm{mg}$ dry weight of freshly prepared cell walls.

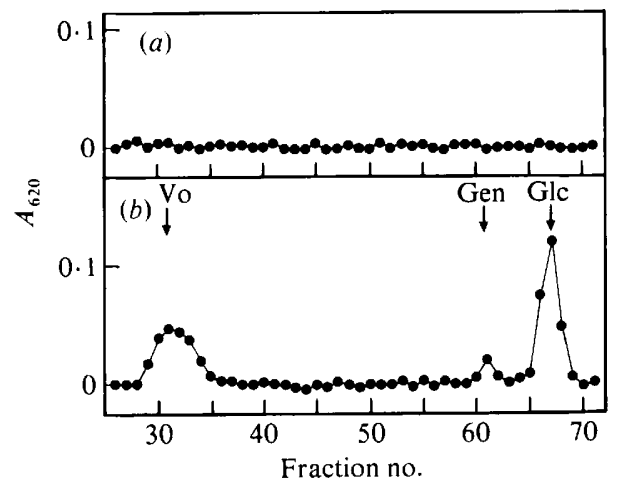

Fig. 2. Bio-Gel P-2 profiles of the sugar liberated after autolysis for $0 \mathrm{~h}(a)$ and $3 \mathrm{~h}(\mathrm{~b})$. A $1 \mathrm{ml}$ portion of the product liberated from the stipe cell walls at the $15 \mathrm{~h}$ stage was applied to a Bio-Gel P-2 column and eluted with Mcllvaine buffer ( $\mathrm{pH} 5.0$ ) containing $0.01 \%(\mathrm{w} / \mathrm{v})$ sodium azide. Fractions of $1 \mathrm{ml}$ were collected and analysed with the anthrone reagent. Vo, void volume; Gen, gentiobiose; Glc, glucose.

limitation was responsible for the reduction in autolysis rate. However, the improvement appeared incomplete; the sugar release during the first $3 \mathrm{~h}$ after the addition of the boiled cell walls was approximately $67 \%$ of that during the first $3 \mathrm{~h}$ of autolysis proper (Fig. 1). This may have been due to insufficient access of the boiled cell walls to autolytic enzymes, or to a progressive loss of enzyme activity with time. A similar phenomenon has been reported for cell wall autolysis in Aspergillus nidulans (Polacheck \& Rosenberger, 1975).

\section{Polymeric nature of autolytically liberated sugar}

The soluble products obtained after $30 \mathrm{~min}$ autolysis were chromatographed on a Bio-Gel P-2 column (Fig. 2). Polymeric (degree of polymerization $>10$ ), dimeric and monomeric 
Table 1. Amounts of polymeric, dimeric and monomeric products liberated during autolysis

Cell walls isolated from stipes $15 \mathrm{~h}$ after the start of illumination on the day of basidiocarp maturation were autolysed for the times indicated, and the liberated products were separated by Bio-Gel P-2 column chromatography as described in Methods. Results are expressed as $\mu \mathrm{g}$ glucose equivalents per mg dry weight of the cell wall.

Time (h)
$0 \cdot 5$
1
3
6
12
24

$\begin{array}{cccr}\text { Polymers* } & \text { Dimers } & \text { Monomers } & \text { Total } \\ 24.2 & 2.3 & 28.7 & 55.2 \\ 24.7 & 2.6 & 57.8 & 85 \cdot 1 \\ 5.5 & 5.5 & 169.3 & 180 \cdot 3 \\ 8.8 & 0 & 283.4 & 292.2 \\ 10.9 & 0 & 353.1 & 364 \cdot 0 \\ 4.0 & 0 & 396.3 & 400 \cdot 3\end{array}$

* Degree of polymerization $>10$.

Table 2. Change in the composition of the cell-wall polysaccharides other than chitin by autolysis

Cell walls isolated from stipes $15 \mathrm{~h}$ after the start of illumination on the day of basidiocarp maturation were fractionated before and after $24 \mathrm{~h}$ autolysis, and the sugar contents in the respective fractions were determined as described in Methods. Results are expressed as $\mu \mathrm{g}$ glucose equivalents per mg dry weight of the cell walls before autolysis.

$\begin{array}{crc}\text { Fraction } & \text { Before autolysis } & \text { After autolysis } \\ \text { I } & 21.4 & 5.4 \\ \text { II } & 47.1 & 94.1 \\ \text { III } & 130.1 & 45.9 \\ \text { IV } & 303.5 & 38.9 \\ \text { Total } & 502.1 & 184.3\end{array}$

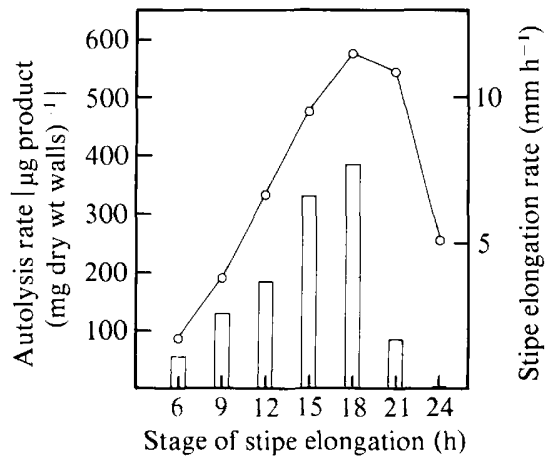

Fig. 3. Relationship between the initial rate of autolysis (O) and stipe elongation (histogram) of Coprinus macrorhizus. Autolysis is expressed as $\mu \mathrm{g}$ anthrone-positive materials released per stipe during the first $3 \mathrm{~h}$ of autolysis at $37^{\circ} \mathrm{C}$ in Mcllvaine buffer ( $\mathrm{pH} \mathrm{5.0)}$. The average of at least three measurements is given for each plot. Elongation rate is based on the data of Kamada \& Takemaru $(1977 a)$. Since the size of basidiocarps varied between culture dishes, basidiocarps of average size (stipe length at the $6 \mathrm{~h}$ stage was approximately $12 \mathrm{~mm}$ ) were selected for the measurements. The abscissa shows hours after the start of illumination on the day of basidiocarp maturation.

components were detected. The time-course study showed that the amount of the polymeric component decreased during the first $3 \mathrm{~h}$ of autolysis, whereas that of the monomeric component gradually increased as the reaction proceeded (Table 1). The dimeric component had completely disappeared by $6 \mathrm{~h}$. These results suggest that both exo- and endomechanisms of glucan hydrolysis are involved in the autolysis reaction. 
Polysaccharide composition of autolysing cell walls

The stipe cell-wall polysaccharides other than chitin are separable into at least four components (Kamada \& Takemaru, 1977b). To investigate which components were solubilized by autolysis, the amounts of the four components in the cell walls before and after autolysis were determined (Table 2). Fractions I, III and IV were highly susceptible to autolytic enzymes, whereas fraction II was not.

\section{Relation between the rates of autolysis and stipe elongation}

Stipe cell walls from various stages of elongation were allowed to autolyse, in order to examine the relation between autolysis and stipe elongation. Changes in the initial rate of autolysis paralleled changes in the elongation rate, although the decrease in elongation rate after the $18 \mathrm{~h}$ stage appeared to progress slightly ahead of the decrease of the autolysis rate (Fig. 3).

\section{DIS C US SION}

A role for cell-wall lytic enzymes in hyphal growth has been suggested (Bartnicki-Garcia \& Lippman, 1972; Bartnicki-Garcia, 1973). Supporting evidence that autolytic enzymes are involved in apical growth and branching of vegetative hyphae has been obtained in a variety of filamentous fungi (Mahadevan \& Mahadkar, 1970; Polacheck \& Rosenberger, 1975; Fèvre, 1977). The present study showed a positive relation between the initial rate of autolysis of stipe cell walls and the rate of stipe elongation, suggesting that autolytic enzymes are involved in the mechanisms of the elongation of stipe cells.

It has been reported that the autolysis of the hyphal wall in Saprolegnia monoica is mostly due to an endo-glucanase (Fèvre, 1977). In the stipe cell wall of $C$. macrorhizus, however, both exo- and endo-glucanases must be involved in autolysis, because both monosaccharide and polysaccharide was liberated during the initial stages of autolysis, and the polysaccharide was converted to monosaccharide as the reaction proceeded (Fig. 2, Table 1). Thus there may be a difference in growth mechanism between vegetative hyphae and stipe cells. Involvement of both exo- and endo-glucanases in the autolysis of cell wall has been reported in the higher plant Zea mays (Huber \& Nevins, 1979, 1980, 1981).

In Aspergillus nidulans, only $3 \%$ of the hyphal wall was solubilized during $48 \mathrm{~h}$ autolysis (Polacheck \& Rosenberger, 1975), and in Saprolegnia monoica, less than $3.6 \mu \mathrm{g}$ sugars per $\mathrm{mg}$ of hyphal wall were released during $18 \mathrm{~h}$ (Fèvre, 1977). On the other hand, cell walls from rapidly elongating stipes of $C$. macrorhizus lost as much as $55 \%$ of their dry weight during $24 \mathrm{~h}$ autolysis. This high autolytic capacity may be a reflection of the conspicuously high rate of stipe elongation in this fungus (Kamada \& Takemaru, 1977a).

The present investigation showed that the polysaccharide components of the stipe cell wall, fractions I, III and IV, were highly susceptible to autolytic enzymes, whereas fraction II was not (Table 2). The amount of fraction II increased during autolysis (Table 2), suggesting that some cell-wall component(s) might be converted to fraction II by structural modification during autolysis. Chitin hydrolysis appeared to be small, since only a small amount of $\mathrm{N}$-acetylglucosamine and/or its polymer was detected in the products of autolysis. These results are consistent with our previous results that the amounts of fraction I, III and IV markedly decrease per unit stipe length as stipe elongation proceeds, whereas that of fraction II is almost constant and that of chitin decreases only slightly (Kamada \& Takemaru, $1977 b$ ). These results also show that fraction II as well as chitin might function as a skeletal component of the stipe cell wall. Further understanding of the function of the respective cell-wall components must await the results of investigations, which are in progress, into their molecular structure.

We wish to thank Dr G. W. Gooday of University of Aberdeen for his critical reading of the manuscript. This work was supported in part by a Grant-in-Aid for Scientific Research to T. K. (no. 454233) from the Ministry of Education, Science and Culture, Japan. 


\section{REFERENCES}

BARTNICKI-GARCIA, S. (1973). Fundamental aspects of hyphal morphogenesis. Symposia of the Society for General Microbiology 23, 245-267.

BARTNICKI-GARCIA, S. \& LipPMAN, E. (1972). The bursting tendency of hyphal tips of fungi: presumptive evidence for a delicate balance between wall synthesis and wall lysis in apical growth. Journal of General Microbiology 73, 487-500.

FAIRBAIRN, N. J. (1953). A modified anthrone reagent. Chemistry and Industry 72, 86.

FĖVRE, M. (1977). Subcellular localization of glucanase and cellulase in Saprolegnia monoica Pringsheim. Journal of General Microbiology 103, 287-295.

Gooday, G. W. (1973). Activity of chitin synthetase during the development of fruit bodies of the toadstool Coprinus cinereus. Biochemical Society Transactions 1, 1105-1107.

GoODAY, G. W. (1975). The control of differentiation in fruit bodies of Coprinus cinereus. Reports of the Tottori Mycological Institute (Japan) 12, 151-160.

Gooday, G. W., De Rousset-Hall, A. \& Hunsley, D. (1976). Effect of polyoxin D on chitin synthesis in Coprinus cinereus. Transactions of the British Mycological Society 67, 193-200.

Griggs, L. J., Post, A., White, E. R., Finkelstein, J. A., Moeckel, W. E., Holden, K. G., Zarembo, J. E. \& Weisbach, J. A. (1971). Identification and quantitation of alditol acetates of neutral and amino sugars from mucins by automated gas-liquid chromatography. Analytical Biochemistry 43, 369381.

Huber, D. J. \& Nevins, D. J. (1979). Autolysis of the cell wall $\beta$-D-glucan in corn coleoptiles. Plant and Cell Physiology 20, 201-212.

HubER, D. J. \& Nevins, D. J. (1980). $\beta$-D-Glucan hydrolase activity in Zea coleoptile cell walls. Plant Physiology 65, 768-773.

Huber, D. J. \& Nevins, D. J. (1981). Partial purification of endo- and exo- $\beta$-D-glucanase enzymes from Zea mays $\mathrm{L}$. seedlings and their involvement in cell-wall autohydrolysis. Planta 151, 206-214.

Kamada, T. \& TAKemaru, T. (1977a). Stipe elongation during basidiocarp maturation in Coprinus macrorhizus: mechanical properties of stipe cell wall. Plant and Cell Physiology 18, 83 I-840.

Kamada, T. \& TAKemaru, T. (1977b). Stipe elongation during basidiocarp maturation in Coprinus macrorhizus: changes in polysaccharide composition of stipe cell wall during elongation. Plant and Cell Physiology 18, 1291-1300.

Kamada, T., Fuji, T. \& Takemaru, T. (1980). Stipe elongation during basidiocarp maturation in Coprinus macrorhizus: changes in activity of cell wall lytic enzymes. Transactions of the Mycological Society of Japan 21, 359-367.

Mahadevan, P. R. \& MahadkaR, U. R. (1970). Role of enzymes in growth and morphology of Neurospora crassa: cell-wall-bound enzymes and their possible role in branching. Journal of Bacteriology 101, 941-947.

McIlvaine, T. C. (1921). A buffer solution for colorimetric comparison. Journal of Biological Chemistry 49, 183-186.

Moore, D., Elhiti, M. M. Y. \& Butler, R. D. (1979). Morphogenesis of the carpophore of Coprinus cinereus. New Phytologist 83, 695-722.

Polacheck, Y. \& Rosenberger, R. F. (1975). Autolytic enzymes in hyphae of Aspergillus nidulans: their action on old and newly formed walls. Journal of Bacteriology 121, 332-337.

Santos, T., Sánchez, M., Villanueva, J. R. \& NombelA, C. (1979). Derepression of $\beta-1,3$ glucanases in Penicillium italicum: localization of the various enzymes and correlation with cell wall glucan mobilization and autolysis. Journal of Bacteriology 137, 6-12.

Wessels, J. G. H. (1965). Morphogenesis and biochemical processes in Schizophyllum commune Fr. Wentia 13, 1-113. 